\title{
Prevalence and Molecular characterization of Shiga toxin producing $E$. coli isolated from some locally produced beef products
}

\author{
*Elbagoury, A.M.;*Shawish, R.R and **Edris, A.M. \\ * Department of Food Hygiene \& Control, Faculty of Veterinary Medicine ,University of \\ Sadat City. \\ ** Department of Food Control, Faculty of Veterinary Medicine, Benha University.
}

\begin{abstract}
Shiga toxin-producing Escherichia coli (STEC) may cause severe gastrointestinal and systematic diseases in humans that result from consumption of meat products. STEC were isolated from some beef products on Trypticase Soya Broth and Sorbitol MacConkey agar supplemented with cefixime and tellurite supplements and were biochemically identified . Further identifications were performed including Vero cells cytotoxicity assay and PCR technique for specific VT1/VT2 and eae genes. It was obvious from the obtained resuts that the incidance of shiga-toxin producing E.coli were $22 \%, 12 \%, 10 \%, 16 \%$ and $2 \%$ in minced meat, beef burger, beef sausage, beef kofta and beef luncheon, respectively. The serovars of shiga-toxin producing E.coli isolated from the examined meat samples were O111, O26, O103, 0119 ,O128 ,O86, O45 ,O146,O119 and O121. E.coli O111, O26, O103, O91, O86 and 0119 that proved to have Stxl and Stx2 genes. E.coli O128 and O121 had only Stxl, while E.coli $\mathrm{O} 146$ had only Stx2.Concerning the eae gene responsible for the attaching and effacing lesions, E. coli $\mathrm{O} 111$ and $\mathrm{O} 26$ isolates proved to possess such gene .In conclusion beef beef products constitute an important reservoir of STEC infection to man and it was decleared that PCR technique is the most rapid, sensitive and efficient approach for detection of STEC in beef products.
\end{abstract}

Keywords: STEC; Serovars; Genotypes; beef products

\section{Introduction}

Shiga toxin-producing E. coli (STEC), also known as verotoxin-producing E. coli (VTEC) or enterohaemorrhagic E. coli (EHEC), have been known as a group of highly pathogenic E. coli strains producing one or more Shiga toxins (Monaghan et al., 2011). STEC represent a hazardous public health problem worldwide causing various human gastrointestinal tract diseases, including watery or bloody diarrhoea, and might develop a lifethreatening disease, such as haemorrhagic colitis"HC", thrombotic thrombocytopenic purpura "TTP" and haemolytic uraemic syndrome "HUS"(Pennington., 2010). 
Shiga toxin-producing Escherichia coli (STEC) strains produce two powerful phage-encoded cytotoxins causing tissue damage in humans and animals, called Shiga toxins or verotoxins (Stx1/VT1 and Stx2/VT2), which are the common feature and main virulence factors of STEC and are directly correlated with human pathogenicity (Lindgren et al., 1993). Stx2 is the most powerful toxin, and toxin producing strains are usually associated with more severe infections (Muniesa et al., 2004 and Gyles, 2007). In addition, some STEC strains can tightly attach and form attaching and effacing lesions to intestinal epithelial cells through an adhesin called intimin, which is encoded by the eae gene.

The aim of the present study was to determine the occurrence, serovars and virulence gene profile of STEC isolated from beef products samples collected at the retail level in Egypt.

\section{Material and methods}

\section{Isolation of STEC from meat product samples:}

This study included 250 random locally produced beef product samples (50 each of minced beef, raw kofta, beef burger, fresh sausage and beef luncheon) were collected from different super markets at Menofia, Cairo and El-Kalyobia governorates, Egypt in clean sterile containers and transported with a minimum of delay to the laboratory.

$25 \mathrm{~g}$ of each beef product was added into $225 \mathrm{ml}$ of Tryptic Soy Broth and incubated overnight at $37{ }^{\circ} \mathrm{C}$. Subculture was done from Tryptic Soya broth on Sorbitol MacConkey Agar (SMAC) with cefixime and tellurite to obtain the suspected colonies of the concerned bacteria .The obtained colonies were prepared for VCA to detect STEC. Positive samples were confirmed to be STEC by PCR reaction to determine the type of Stx and serotyping. (Konowalchuk et al., 1977).

\section{Vero cell assay of the suspected $E$. coli strains}

The cytotoxicity of the suspected $E$. coli isolates for vero cells was determined by using tissue culture supernatant and thereby detecting only high level of production of these cytotoxins based on Konowalchuk et al. (1977).

This test was carried out in 96 well tissue culture plates. $90 \mu \mathrm{L}$ of sterile physiological saline was added to each of the test wells, while $50 \mu \mathrm{L}$ of the physiological saline was added to the negative control wells. $60 \mu \mathrm{L}$ of the bacterial lysates was added to each well. $50 \mu \mathrm{L}$ of RPMI medium containing $10 \%$ calf serum, 2mM L-glutamin, $100 \mathrm{U}$ penicillin/ml and $100 \mu \mathrm{g}$ streptomycin $/ \mathrm{ml}$ were added to each one of the test wells. A suspension of vero cells was prepared and $50 \mu \mathrm{L}$ of this suspension was seeded in each well of the test wells. $50 \mu \mathrm{L}$ of $1 \%$ SDS solution was added to each of the positive control wells. The plates were incubated at 
$37^{\circ} \mathrm{C}$ in $5 \% \mathrm{CO} 2$ atmosphere, observed daily by using inverted microscope for detection of cell lysis and vacuolation.

\section{Serotyping $E$. coli isolates}

The isolates were serologically identified according to Kok et al. (1996) by using rapid diagnostic E.coli antisera sets (DENKA SEIKEN Co., Japan) for detection of the Shiga toxin-producing Escherichia coli serovars.

Detection of Stx1, Stx 2 and $e a e$ genes of STEC isolated from beef product samples using Multiplex PCR:

The multiplex PCR was performed as described by Paton and Paton, 1998 at the laboratory of infectious diseases and Internal medicine, faculty of Veterinary Medicine, University of Sadat City, Egypt.

Genomic DNA extraction: Chromosomal DNA was isolated from STEC isolates using GeneJET Genomic DNA Purification Kit (Fermentas)

\section{DNA amplification for MULTIPLEX-PCR reaction.}

$20 \mathrm{ng}$ of chromosomal DNA was used per reaction, where amplifications were performed in 25ul of buffer solution containing $3 \mathrm{uM}$ of oligonucleotides, 200uM of each deoxynucleoside triphosphate, $3.5 \mathrm{mM} \mathrm{MgCl} 2$ and 2.5U of DNA Taq polymerase.Mixtures were overlaid with mineral oil and amplification was performed in PCR thermal cycler. Samples were subjected to $35 \mathrm{PCR}$ cycles, each consisting of 1 min of denaturation at $95^{\circ} \mathrm{C} ; 2 \mathrm{~min}$ of annealing at $65^{\circ} \mathrm{C}$ for the first 10 cycles, decrementing to $60^{\circ} \mathrm{C}$ by cycle 15 ; and $1.5 \mathrm{~min}$ of elongation at $72^{\circ} \mathrm{C}$,incrementing to $2.5 \mathrm{~min}$ from cycles 25 to 35 . Amplified DNA fragments were resolved by gel electrophoresis (Sambrook et al, 1989) using $2 \%(\mathrm{w} / \mathrm{v})$ agarose. Gels were stained with $0.5 \mathrm{mg}$ of ethidium bromide per $\mathrm{ml}$ for $15 \mathrm{~min}$, and documented with a UVP documentation system.

Primer sequence of shiga toxin producing E.coli.

\begin{tabular}{|l|l|l|l|}
\hline Gene & \multicolumn{1}{|c|}{ Primer sequence } & $\begin{array}{c}\text { Predicted } \\
\text { size }\end{array}$ & \multicolumn{1}{|c|}{ Reference } \\
\hline Stx1 & $\begin{array}{l}\text { 5'- ATAAATCGCCATTCGTTGACTAC -3' } \\
\text { 5'-AGAACGCCCACTGAGATCATC - 3' }\end{array}$ & $180 \mathrm{bp}$ & $\begin{array}{l}\text { Paton and Paton } \\
(1998)\end{array}$ \\
\hline Stx2 & $\begin{array}{l}\text { 5'- GGCACTGTCTGAAACTGCTCC -3' } \\
\text { 5'- TCGCCAGTTATCTGACATTCTG -3' }\end{array}$ & $255 \mathrm{bp}$ & $\begin{array}{l}\text { Paton and Paton } \\
(1998)\end{array}$ \\
\hline eae & $\begin{array}{l}\text { 5' GCATCACAAGCGTACGTTCC 3 ' } \\
\text { 5' CCACCTGCAGCAACAAGAGG 3' }\end{array}$ & $384 \mathrm{bp}$ & $\begin{array}{l}\text { Paton and Paton } \\
(1998)\end{array}$ \\
\hline
\end{tabular}


Results

Table (1): Incidence of Shiga toxin producing $E$. coli (STEC) in the examined beef product samples using Vero-Cytotoxicty assay and Multiplex PCR .

\begin{tabular}{|c|c|c|c|}
\hline Beef products & $\begin{array}{c}\text { No. of examined } \\
\text { samples }\end{array}$ & \multicolumn{2}{|c|}{ No. of positive STEC samples } \\
\cline { 3 - 4 } & & VCA & Multiplex PCR \\
\hline Minced meat & 50 & $14(28 \%)$ & $11(22 \%)$ \\
\hline Beef burger & 50 & $7(14 \%)$ & $6(12 \%)$ \\
\hline Beef sausage & 50 & $7(14 \%)$ & $5(10 \%)$ \\
\hline Beef kofta & 50 & $9(18 \%)$ & $8(16 \%)$ \\
\hline Beef luncheon & 50 & $1(2 \%)$ & $1(2 \%)$ \\
\hline
\end{tabular}

Table (2): Incidence of Shiga toxin producing $E$. coli (STEC) serovars isolated from examined beef product samples.

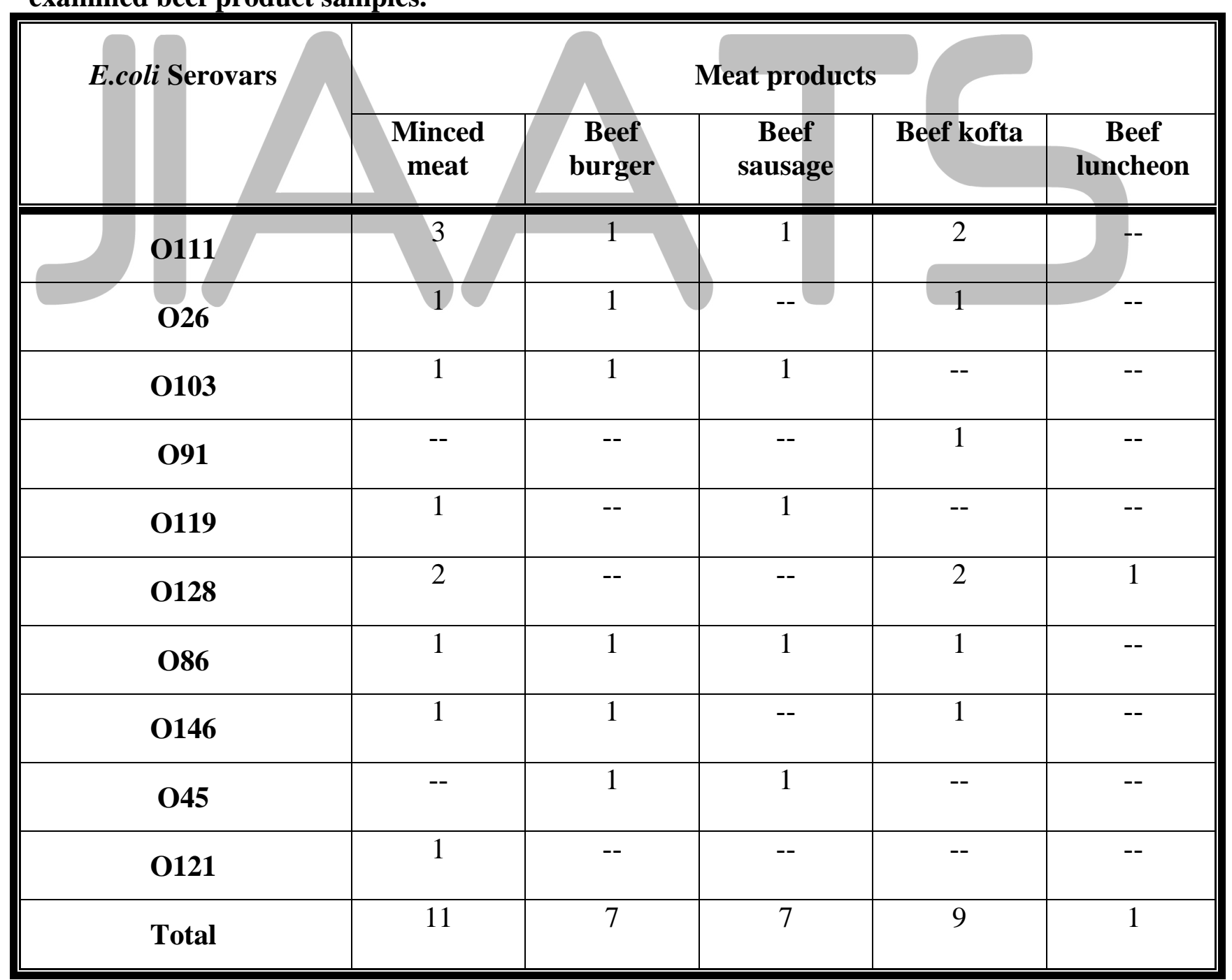


Table (3): Occurrence of some virulence genes in serovars of Shiga toxin-producing E.coli (STEC) isolated examined meat product samples.

\begin{tabular}{|c|c|c|c|c|c|c|c|c|c|}
\hline \multirow{2}{*}{ Serovars } & \multirow{2}{*}{$\begin{array}{c}\text { No. of ex. } \\
\text { isolates }\end{array}$} & \multicolumn{2}{|c|}{ Stx1 alone } & \multicolumn{2}{|c|}{ Stx2 alone } & \multicolumn{2}{c|}{ Stx1\&Stx2 } & \multicolumn{2}{c|}{ Eae } \\
\cline { 3 - 10 } & & NO. & $\%$ & NO. & $\%$ & No. & $\%$ & No. & $\%$ \\
\hline \hline O111 & 7 & 6 & 85.7 & 7 & 100 & 6 & 85.7 & 5 & 71.4 \\
\hline O26 & 3 & 2 & 66.6 & 3 & 100 & 2 & 66.6 & 2 & 66.6 \\
\hline 0103 & 3 & 1 & 33.3 & 2 & 66.6 & 2 & 66.6 & 0.0 & 0.0 \\
\hline 091 & 1 & 1 & 100 & 1 & 100 & 1 & 100 & 0.0 & 0.0 \\
\hline 0119 & 2 & 1 & 50 & 2 & 100 & 1 & 50 & 0.0 & 0.0 \\
\hline 0128 & 5 & 5 & 100 & 0.0 & 0.0 & 0.0 & 0.0 & 0.0 & 0.0 \\
\hline 086 & 4 & 0.0 & 0.0 & 4 & 100 & 0.0 & 0.0 & 0.0 & 0.0 \\
\hline 0146 & 3 & 0.0 & 0.0 & 3 & 100 & 0.0 & 0.0 & 0.0 & 0.0 \\
\hline 045 & 2 & 2 & 100 & 0.0 & 0.0 & 0.0 & 0.0 & 0.0 & 0.0 \\
\hline 0121 & 1 & 0.0 & 0.0 & 1 & 0.0 & 0.0 & 0.0 & 0.0 & 0.0 \\
\hline
\end{tabular}

Photo (1): Cytotoxic effect of Shiga toxin containing bacterial lysate of STEC on Vero cells.

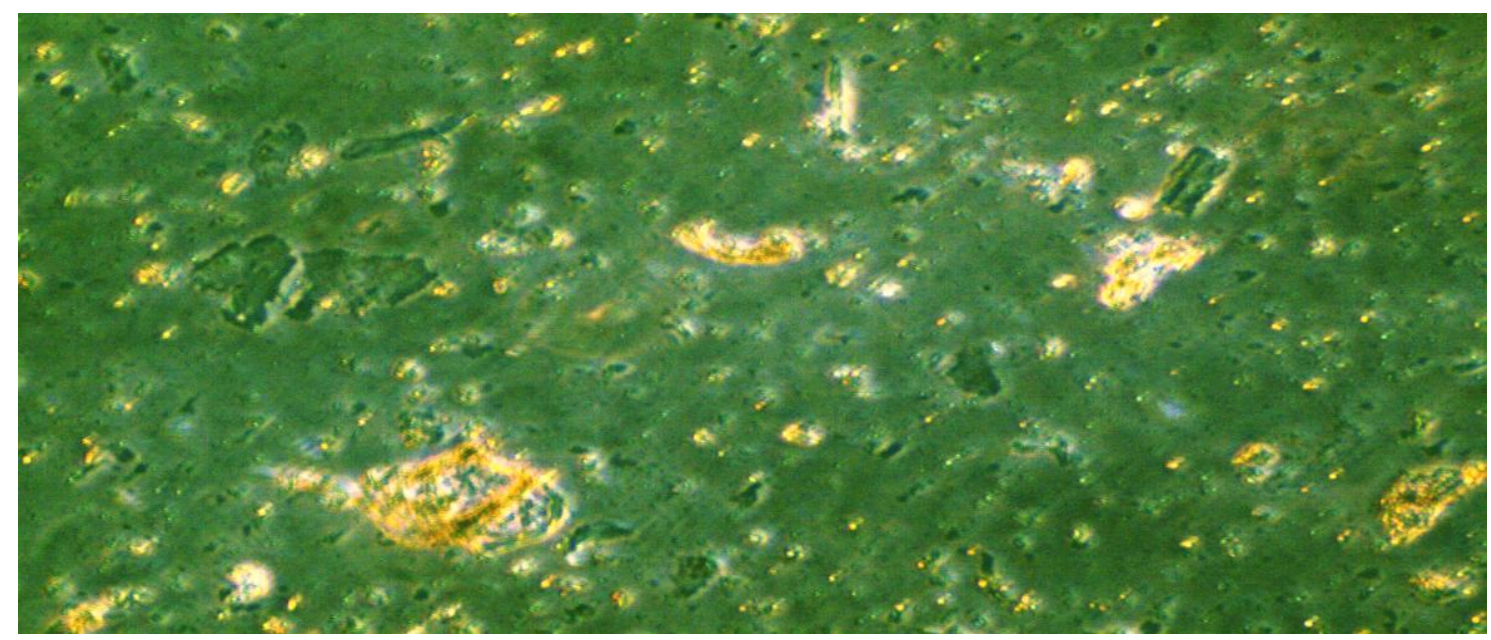

The Cytopathic effects of Shiga toxin containing bacterial lysate of STEC were observed after incubation with culture filtrates there was a change from spindle-shaped cells characteristic of normal Vero cells to round and shriveled cells, and these changes were followed by gradual destruction of the monolayer. 
Photo (2) Agarose gel shows five positive strains of EHEC for shiga toxin 1 and shiga toxin 2 and eae genes. $180 \mathrm{bp}, 255 \mathrm{bp}, 384 \mathrm{bp}$ respectively.

Lane (M): MW marker $=100$ bp DNA ladder (Promega).

Lane 1- $\mathrm{O}_{111}$ has the 3 genes stx 1 , stx 2 and eae genes

Lane 2- $\mathrm{O}_{86}$ has stx 2 genes

Lane 3- $\mathrm{O}_{121}$ has stx2 genes

Lane 4- $\mathrm{O}_{26}$ has the 3 genes stx 1 , stx 2 and eae genes

Lane 5- $\mathrm{O}_{103}$ harbor stx 1 and stx2genes

Lane 6- negative control

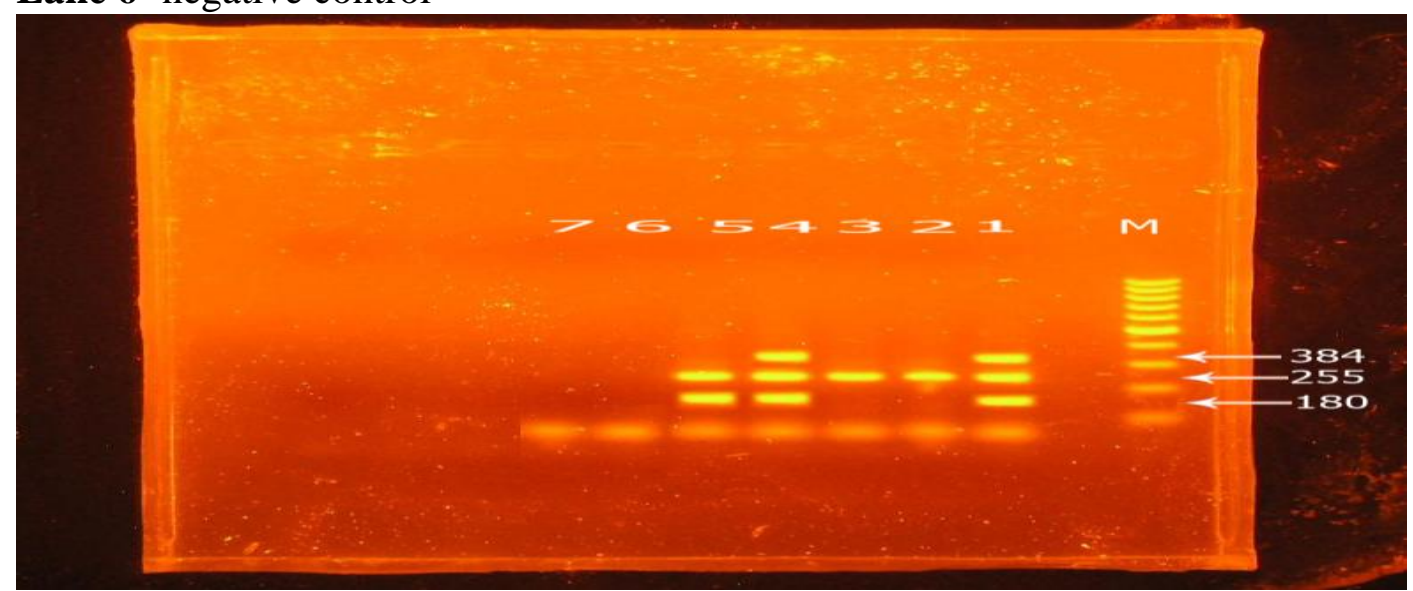

Photo (3) Agarose gel shows six positive strains of EHEC for shiga toxin 1 and shiga toxin 2 and eae genes. $180 \mathrm{bp}, 255 \mathrm{bp}, 384 \mathrm{bp}$ respectively. Lane (M): MW marker $=100$ bp DNA ladder (Promega). Lane 1- $\mathrm{O}_{111}$ has the 3 genes stx 1 , stx 2 and eae genes Lane 2- $\mathrm{O}_{146}$ harbor stx 2 genes Lane 3- $\mathrm{O}_{91}$ harbor stx 1 and stx2genes Lane 4- $\mathrm{O}_{103}$ harbor stx 1 and stx2genes Lane $5-\mathrm{O}_{45}$ has stx 1 genes

Lane 6- negative control.

Lane 7- $\mathrm{O}_{86}$ has stx2 genes

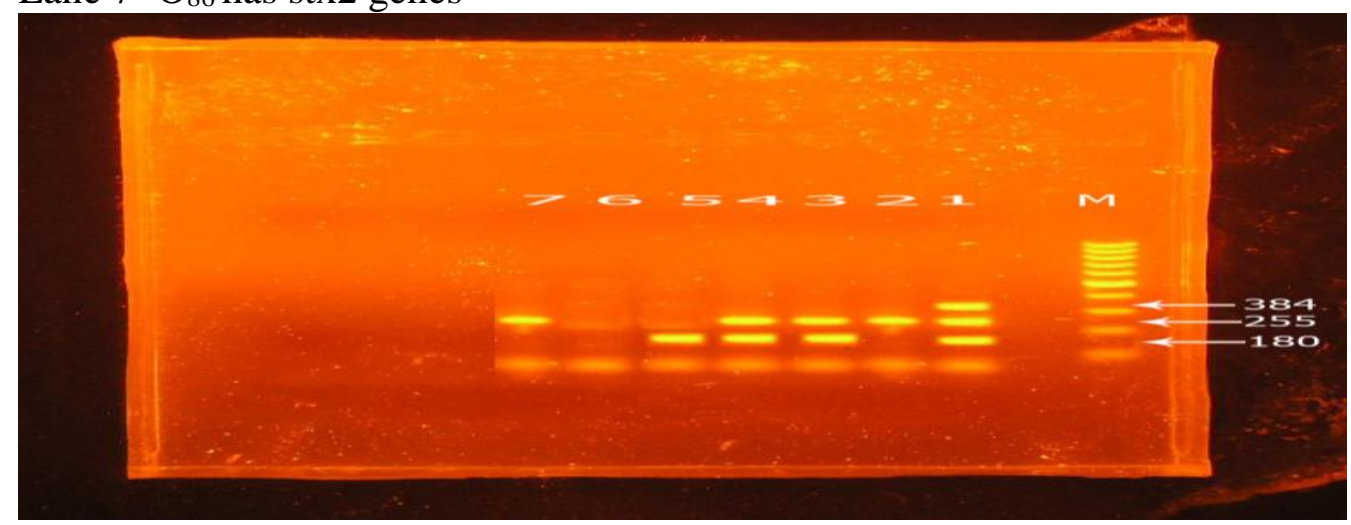

Photo (4) Agarose gel shows seven positive strains of EHEC for shiga toxin 1 and shiga toxin 2 and eae genes. $180 \mathrm{bp}, 255 \mathrm{bp}, 384 \mathrm{bp}$ respectively.

Lane (M): MW marker $=100$ bp DNA ladder (Promega).

Lane $1-\mathrm{O}_{111}$ has the 3 genes stx 1 , stx 2 and eae genes

Lane 2- $\mathrm{O}_{128}$ harbor stx 1 genes

Lane 3- $\mathrm{O}_{146}$ harbor stx 2 genes

Lane 4- $\mathrm{O}_{45}$ harbor stx 1 genes 
Lane 5- $\mathrm{O}_{86}$ has stx2 genes

Lane 6- $\mathrm{O}_{119}$ harbor stx1 and stx2genes

Lane 7- $\mathrm{O}_{86}$ has stx2 genes

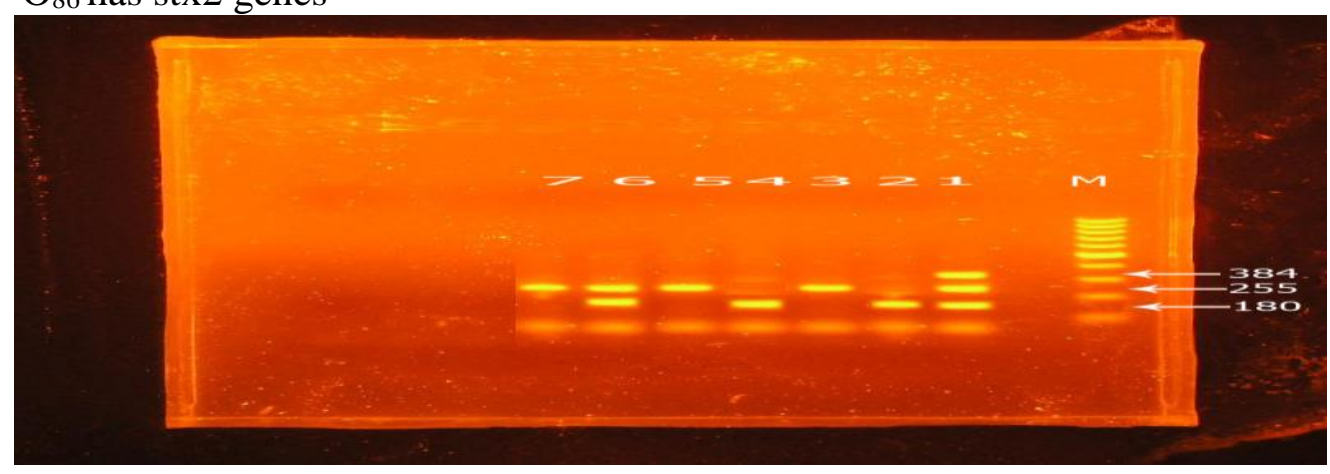

Discussion

Shiga toxin-producing E. coli (STEC) is a serious public health concern worldwide. This pathogen causes diarrhea, hemorrhagic colitis and hemolytic-uremic syndrome .Shiga toxin produced by STEC has been considered a prime virulence factor. Shiga toxins are classified into two groups, Stx 1 and Stx2, on the basis of immunological properties. Though O157:H7 is the most predominant serovare isolated from sporadic cases and outbreaks, more than 100 serovars of non-O157 STEC have been isolated from animals and humans ( Abd -EL-All , 2005). Since most of the food poisonings due to STEC are related to the consumption of beef or beef products, cattle have been considered a major reservoir of STEC. However, other vehicles, such as contaminated water, vegetables, and fruits, have been increasingly recognized as an infection source of STEC (Shima, et al., 2006).

The occurrence of Shiga toxin-producing E. coli (STEC) in beef products as examined by Vero Cytotoxicity Assay (VCA) and Multiplex Polymerase Chain Reaction was illustrated in table(1).

The obtained results revealed that $28 \%, 14 \%, 14 \%, 18 \%$ and $2 \%$ of minced meat, beef burger, beef sausage, beef kofta and beef luncheon respectively were contaminated with shiga toxin producig E. coli using Vero-Cytotoxicty assay method assay .

The Cytotoxic effect of shiga toxin cotaining bacterial lysate on vero cells was illustrated in photo(1). In the present study vero cytotoxicity assays was used as screening test for STEC. The test was done only on samples that gave characteristic colonies on sorbitol monitol agar plates. Detection of STEC was done on basis of positive VCA. The positive samples were confirmed by serotyping using polyvalent and monovalent " O" Escherchia coli antisera. Further confirmation was done by using multiplex PCR reaction to determine the type of Stx. 
The profound sensitivity of Vero cells to Stx was first observed by Konowalchuk et al. (1977), and cytotoxicity for this cell line remains the "gold standard" for confirmation of positive STX-producing isolates (Byomi, 1991).

Paton and Paton, (1998) stated that Vero cytotoxicity assay has played an important role in establishing a diagnosis of STEC infection, particularly where subsequent isolation of the causative organism has proven to be a difficult task. When testing such crude samples, the sensitivity is influenced by the abundance of STEC, the total amount and potency of the STX produced by the organism concerned, and the degree to which the particular STX is released from the bacterial cells.

Table (1) revealed that shiga-toxin producing E. coli also can be detected by Mutiplex PCR in minced meat, beef burger, beef sausage, beef kofta and beef luncheon by the following ratio $22 \%, 12 \%, 10 \%, 16 \%$ and $2 \%$ respectively. PCR provide rapid and valuable diagnostic method while, detection of Stx by tissue culture cytotoxicity is labor-intensive, time-consuming, and cumbersome. Not all microbiology laboratories perform tissue culture work with Vero cell monolayers available on demand. Moreover, rapid diagnosis is important, and the results of cytotoxicity testing are generally not available befor 48 to $72 \mathrm{hrs}$. (Paton and Paton, 1998). The current results agree, to some extent, with those recorded by (Hussein \& Bollinger (2005) and Hussein (2007) as they found non O157 STEC to be more prevalent in beef products than E. coli O157. The prevalence rates of non O157 STEC ranged from 2.4 to $30.0 \%$ in ground beef, from 17.0 to $49.2 \%$ in sausage. Testing other beef products revealed prevalence rates of 19.0\% (Zhao et al., 2001) and 62.5\% (Samadpouret al., 1994).

However, (Smith and Scotland, 1988.) pointed out that the two examined samples were positive VCA and were confirmed to be non-STEC, Since the presence of cytoxicity in a crude filtrate could be due to other bacterial products or toxins, positive samples should always be confirmed and typed by testing for neutralization of cytotoxicity by specific preferably monoclonal antibodies to Stx1 or Stx2. Moreover, Abd-El-Latif (2003) detected two STEC which were positive for VCA while only one of them was positive to PCR.

Table (2) revealed that the serological identification of shiga-toxin producing E.coli isolated from the examined minced meat samples were O111, O26, O103, 0119 ,0128, O86, O146 and $\mathrm{O} 121$, from beef burger samples, the isolated serovars O111, O26, 0103 ,O86, O146 and $\mathrm{O} 45$. But the isolated serovars from beef sausage were $\mathrm{O} 111, \mathrm{O} 103, \mathrm{O} 119 \mathrm{O} 86$ and $\mathrm{O} 45$, while those from beef kofta were O111, O26, O91 ,O128, O86, and O146. finally the only one serovars isolated from beef luncheon was $\mathrm{O} 119$. 
Fantelli and Stephan (2001) detected EHEC or STECin 2.3\% of minced meat samples, while Saleh (2001) isolated EHEC from minced meat, burger and sausage in 16\% of the samples.

Shiga toxin producing E. coli (STEC) organism of different serovars have been isolated from human and from apparently healthy domestic animals .Many of these isolates were typical STEC belonging to serovars O26, O111 and O157 (Karamali, 1989). Also, verotoxin producing E. coli (VTEC) non O157 serovars O26, O103, O111 are among the most important emergency food borne pathogen groups particularly O26 which able to cause large spectrum of illness in human as hemorrhagic colitis (HC) to hemolytic uremic syndrome (HUS) and thrombotic thrombocytopenic purpura (TTP) (Dambrosio et al., 2007).

Enterohaemorragic Escherichia coli (EHEC) constitutes a subset of STEC serovars including E.coli O157 and non - O157 serogroups like O26, O111, O103, and O145. STEC may be transmitted from animal reservoirs to human not only via ingestion of contaminated food or water but also by contact with STEC-positive animal or with their environment (Alfredo et al., 2005).

Enterohaemorrhagic E.coli (EHEC): produces two types of illness, haemorrhagic colitis and hemolytic uraemic syndrome (HUS). Haemorrhagic colitis results from colonic mucosal oedema, errosion and haemorrhage. The incubation period is 3 to 4 days. The symptoms start by sudden pain followed by watery diarrhea, nausea and vomition in the early stages of illness and abdominal distension with severe pain after the onset, disease progress over 2 days to bloody diarrhea. Haemorrhagic colitis was primarily foodbrone and was associated most frequently with E. coli. as recorded by Riley (1987), Bhong et al. (2008), Lee et al. (2009) and Xiaodong (2010).

Table [3] illustrates STEC isolated from meat product samples have virulence genes. The use of Multiplex PCR with specific primers for Stx1, Stx2 ,eae and ehly genes revealed the presence or absence of these genes in the tested isolates. The obtained results showed that the isolates E. coli O111, O26, O103, O91, O86 and O119 had Stx1 and Stx2 genes while, E.coli O128 and O121 had only Stx1. E.coli O146 had only Stx2.Concerning the eae gene responsible for the attaching and effacing lesions, E. coli $\mathrm{O} 111$ and $\mathrm{O} 26$ isolates possessed this gene .

According to, Hornitzky et al.(2002); Jenkenis et al.(2002) ; Bollinger (2004) and Hassanain and Ahmed (2008) stated that serotypes O111, O26, O103, O128, O121, O91, O86 and O119 are Shiga toxin-producing E. coli (STEC). All of the STEC isolates produced 1, 2, 3 or 4 virulence factors (i.e. Stx1, Stx2, Stx1\&stx2 or eae) and were lethal to Vero 
(African green monkey cells). Therefore, the potential public health risk of these isolates should not be ignored.

Photo(2) agarose gel shows five strains of EHEC positive for shiga toxin 1 and shiga toxin 2 and eae genes. At size180 bp, 255bp, 384 bp. respectively. Lane 1 and 4 include O111 and $\mathrm{O} 26$ which contain the three genes stx1,stx 2 and eae so it contains 3 bands. Lane 2 and 3 contain PCR products of O86 and O121 it carry stx 2 genes so we can detect 1 bands appear in the agarose while lane 5 include $\mathrm{O} 103$, it carry stx 1 and stx 2 genes so we can detect 2 bands.

Photo(3) agarose gel shows six strains of EHEC positive for shiga toxin 1 and shiga toxin 2 and eae genes. At size 180 bp, 255bp, 384 bp. respectively. Lane 1include O111 which contain the three genes stx1,stx 2 and eae so it contains 3 bands. Lane 2 and 7 contain PCR products of $\mathrm{O} 146$ and $\mathrm{O} 86$, it carry stx 2 genes so we can detect 1 bands appear in the agarose. Lane 3 and 4 contain PCR products of $\mathrm{O} 91$ and $\mathrm{O} 103$, it carry stx 1 and stx 2 genes so we can detect 2 bands.

Photo(4) agarose gel shows seven strains of EHEC positive for shiga toxin 1 and shiga toxin 2 and eae genes. At size 180 bp, 255bp, 384 bp. respectively. Lane linclude O111 which contain the three genes stx 1 ,stx 2 and eae so it contains 3 bands. Lane 2 and 4 contain PCR products of $\mathrm{O} 128$ and $\mathrm{O} 45$, it carry stx 1 genes so we can detect 1 bands appear in the agarose. Lane 3, 5 and 7 contain PCR products of $\mathrm{O} 146$ and O86, it carry stx 2 genes so we can detect 1 bands appear in the agarose. Lane 6 contain PCR products of O119, it carry stx 1 and stx 2 genes so we can detect 2 bands.

In Egypt, many studies have been reported the prevalence of E.coli O157 in meat or milk products ( Sayed et al.,2001; Mohammed, 2002, , Abd-Ell-All, 2005 and Hassan and ELMalt, 2008) while, few studies have reported the prevalence of non-O157 (Byomi et al., 2001 and Abd-El-All, 2005).

Bettleheim (2000) reported that STEC serovars other than O157H7, such as O111, O103, $\mathrm{O} 26$, and $\mathrm{O} 145$ are emerging human pathogens predominantly in Europe, Australia, and South America.

\section{Reference}

Abd -EL-All, A. M. (2005): Prevalence of shiga-toxin producing E. coli in farm animals with reference to environmental sanitation. Ph.D. Thesis, Fac. Vet. Med. Zagazig Univ. Egypt. 
Abd-EL-Lateif, G. S. (2003): Polymerase chain reaction and electrophoretic pattern of certain types of Eschershia coli. M.V.SC. Fac.Vet. Med. Alex. Univ.Egypt.

Alfredo C.; Stefano M, Hubert and Eric O. (2005): Enterohaemorrhagic Escherichia coli emerging issues on virulence and mode of transmission.Vet.Res.,36:289-311.

Bettleheim, K.A .(2000): Role of non-O157 VTEC. J. Appl. Microbiol. Symp. Suppl;88:38S$50 \mathrm{~S}$.

Bhong, C.D.; Brahmbhatt, M.N.; Joshi, C.G. and Rank, D.N.(2008): Detection of virulence determinants by real time PCR in E. coli isolated from mutton. Meat Science, $80: 1129-1131$.

Bollinger, L.M. (2004): Effects of season and animal factors on prevalence of shiga toxinproducing E. coli in beef cattle. MS.V.Sc., Univ. of Nevada, Reno. United States.

Byomi, A.M.; Radwan, G.s. and Bahy El-Gamal G. Abd El-Aal (2001): Chacterization of Shiga toxin producing E.coli (stx1) from bovine by colony blot hybridization and its public health importance. Egypt. J. Biomed. Sci., 7:9-16.

Dambrosio A.A., Lorusso V.V., Quaglia, N.C., Virgilio G.S., Lucifora G.V. and Celano N.F. (2007): Escherichia coli $\mathrm{O} 26$ in minced beef: prevalence, characterization and antimicrobial resistance pattern. Inter J. Food Microbiol. 118: 218-222.

Fantelli, K.and Stephan, R. (2001): Prevalence and characteristics of Shigatoxin-producing Escherichia coli and Listeria monocytogenes strains isolated from minced meat in Switzerland. International Journal of Food Microbiology, 70 : 63-69

Gyles, C.L. (2007) Shiga toxin-producing Escherichia coli: anoverview. J Anim Sci 85, E45E62.

Hassan, S.A. and Elmalt, L.M (2008): Informally raw milk and Kareish cheese investigation on the occurance of toxigenic Escherichia coli in Qena city, Egypt with emphasis on molecular characterization. Ass. Univ. Bull. Environ. Res. 11(2): $35-42$.

Hussein . H. S.,(2007): Prevalence and pathogenicity of Shiga toxin-producing Escherichia coli in beef cattle and their products. J. Anim. Sci. 2007. 85(E. Suppl.):E63E72 doi:10.2527/jas.2006-421.

Hussein, H. S., and L. M. Bollinger.( 2005): Prevalence of Shiga toxinproducing Escherichia coli in beef. Meat Sci. 71:676-689.

Hornitzky, M.A.; Vanselow, B.A.; Walker, K.; Bettelheim, K.A.; Corney, B.; Gill, P.;Baily, G. and Djordjeevic, S.P.(2002): Virulence properties and serotypes 
of shiga toxin-producing E. coli from healtrhy Australian cattle. Appl. Environm. Microbiol. 68:6439-6445.

Jenkins, C.; Pearce, M.C.; Chart, H.; Cheasty, T.; Willshaw, G.A.; Gunn, G.J.; Dougan, G.; Smith, H.R.; Synge, B.AS. and Frankel, G. (2002): An eightmonth study of a population of verocytotoxin-producing Escherichia coli (VTEC) in a Scottish cattle herd. J. Apll. Microbiol., 93: 944-953.

Karmali, M.A. (1989): Infection by Verocytotoxin-producing Escherichia coli. Clinical Microbiology .Rev. 2:15- 38.

Konowalchuk, J.; Speirs, J. I. and Stavric, S. (1977). Vero response to a cytotoxin of Escherichia coli. Infect. Immun. 18:775-779.

Kok, T.; Worswich, D. and Gowans, E. (1996): Some serological techniques for microbial and viral infections. In Practical Medical Microbiology (Collee, J.; Fraser, A.; Marmion, B. and Simmons, A., eds.), $14^{\text {th }}$ ed., Edinburgh, Churchill livingstone, UK.

Lee,G.Y.; Jang,H.I.; Hwang,I.G. and Rhee,M.S.(2009): Prevalence and classification of pathogenic Escherichia coli isolated from fresh beef, poultry, and pork in Korea. International Journal of Food Microbiology, 134 : 196-200.

Lindgren, S.W., Melton, A.R. and O'Brien, A.D. (1993):Virulence of enterohemorrhagic Escherichia coli 091:H21clinical isolates in an orally infected mouse model. Infect Immun 61, 3832-3842..

Mohammed, M. E.M. (2002): Epidemiological studies on some zoonotic bacteria of foodborne diseases. Ph.D. Thesis, Fac. Vet. Med. Zagazig Univ. Egypt.

Monaghan, A., Byrne, B., Fanning, S., Sweeney, T., McDowell,D. and Bolton, D.J. (2011) Serotypes and virulence profiles of non-O157 Shiga toxin-producing Escherichia coli isolates from bovine farms. Appl Environ Microbiol 77,86628668 .

Muniesa, M., Blanco, J.E., De Simon, M., Serra-Moreno, R.,Blanch, A.R. and Jofre, J. (2004) Diversity of stx 2 converting bacteriophages induced from Shiga-toxin producing Escherichia coli strains isolated from cattle.Microbiology 150, 2959-2971.

Paton, J.C. and Paton, A. W. (1998): Pathogenesis and diagnosis of Shiga- toxin-producing Escherichia coli infections. Clin. Microbiol. Rev. 11(3):450-479.

Pennington, H. (2010) Escherichia coli O157. Lancet, 376,1428-1435. 
Riley, L.W. (1987): The epidemiological clinical and microbiological features of hemorrhagic colitis. Annual Review of Microbiol., 41: 383-407.

Saleh, S.K. (2001): Prevalence of Enterohemorrhagic E.coli in some meat products. J. Egypt. Vet. Med. Ass., 61(4): 173-178.

Sambrook, J.; Fritsch, E. F. and Maniatis, T. (1989): Molecular cloning: Laboratory Manual. $2^{\text {nd }}$ Edition, Cold spring, Harbor, New York, USA.

Sayed, A.M.; Abou El- Alla, A.A.; Abd El-Hafez, M.M.; Hussein, A.A.; and Hassanien, Z.A. (2001): Prevalence of Escherichia coli with special reference to E.coli $\mathrm{O}_{157}: \mathrm{H}_{7}$ in some retail meat products in Assiut Governorate. Assiut. Vet. Med. J., 45(90): 146-155.

Shima, K; Wu, Y ; Sugimoto,N; Asakura,M; Nishimura,K and Yamasaki, S (2006): Comparison of a PCR-Restriction Fragment Length Polymorphism(PCRRFLP) Assay to Pulsed-Field Gel Electrophoresis To Determine the Effect of Repeated Subculture and Prolonged Storage on RFLP Patterns of Shiga Toxin Producing Escherichia coli O157:H7._J. CLinc. Mcrbiol., 44(11): 3963-3968

Smith, H. R., and Scotland, S. M. (1988): Vero cytotoxin-producing strains of Escherichia coli. J. Med. Microbiol. 26:77-85.

Samadpour, M., J. E. Ongerth, J. Liston, N. Tran, D. Nguyen, T. S.Whittman, R. A. Wilson, and P. I. Tarr.(1994).:Occurrence of Shiga-like toxin-producing Escherichia coli in retail fresh seafood,beef, lamb, pork, and poultry from grocery stores in Seattle,Washington. Appl. Environ. Microbiol. 60:10381040.

Xiaodong, X.(2010): Pathogenic E.coli in retail meats. Dissertation submitted to the Faculty of the Graduate School of the University of Maryland, College Park, in partial fulfillment of the requirements for the degree of Doctor of Philosophy 2010

Zhao, C., B. Ge, J. De Villena, R. Sudler, E. Yeh, S. Zhao, D. G. White,D. Wagner, and J. Meng. (2001). Prevalence of Campylobacter spp., Escherichia coli, and Salmonella serovars in retail chicken,turkey, pork, and beef from the Greater Washington, DC area.Appl. Environ. Microbiol. 67:5431-5436. 